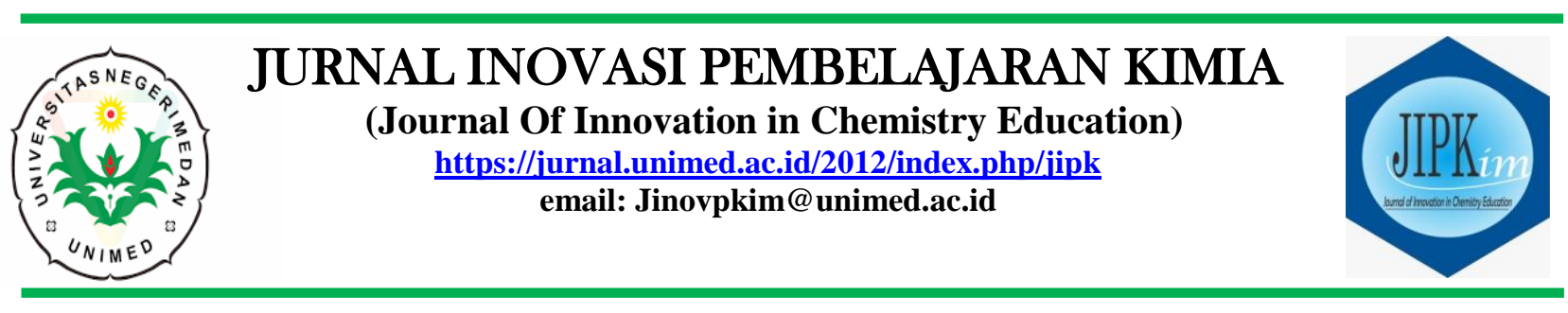

$\begin{array}{ll}\text { Masuk } & : \text { 10 Juli } 2021 \\ \text { Revisi } & : \text { 20 September } 2021 \\ \text { Diterima } & : 24 \text { Oktober } 2021 \\ \text { Diterbitkan } & : \text { 31 Oktober } 2021 \\ \text { Halaman } & : 164-175\end{array}$

\title{
Pengembangan Modul Pembelajaran Kimia Berbasis Proyek Pada Pokok Bahasan Termokimia Untuk Kelas XI SMA
}

\author{
Marudut Sinaga ${ }^{1 *}$, Dian Michael Sagala ${ }^{1}$ \\ ${ }^{1}$ Program Studi Pendidikan Kimia, Universitas Negeri Medan, Medan \\ *Alamat Korespondensi: marudutsng@gmai.com
}

\begin{abstract}
This study aims to 1) find out the thermochemical learning modules developed have met project-based learning $(P j B L), 2)$ the chemistry learning module developed on thermochemical material is in accordance with the criteria set by the BSNP, and 3) students respond to aspects of the appearance, material, and benefits of PjBL thermochemical modules. The research method is $R \& D$ with the ADDIE development model. The sample set in this research is 1) Chemistry Lecturer at UNIMED as many as 3 people, 2) Chemistry teacher at SMAN 2 P.S Tuan as many as 3 people, and 3) Class XI science students at SMAN 2 P.S Tuan. The results show that books A\&C are not based on PjBL, validation of the PJBL model in the module obtained a content aspect score of 3.12 with appropriate criteria, activity aspect has a score of 3.30, the condition aspect has a score of 3.50, and the outcome aspect has a score of 3.50 and the criteria are very feasible. The results of the BSNP standardization obtained a content feasibility value of 2.98 with appropriate criteria; and presentation feasibility 3.36; chart feasibility 3.33; the feasibility of the language is 3.36. The module is suitable for use as teaching.
\end{abstract}

Keywords: Thermochemical, Modules, Project Based Learning, BSNP, Student Response

\section{PENDAHULUAN}

Kimia merupakan bidang studi yang dianggap sulit oleh sebagian besar siswa menengah atas. Hal ini terjadi akibat dari hasil interpretasi bahwa materi kimia bersifat abstrak. Materi kimia pun semakin dianggap sulit karena keterbatasan waktu yang digunakan disekolah dalam mempelajari bidang studi ini. Kimia sebagai bagian dari sains mempelajari fenomena alam berdasarkan kegiatan eksperimen. Terdapat empat dimensi sains yaitu sains sebagai cara berfikir, penyelidikan, kumpulan pengetahuan, serta interaksi sains dengan teknologi dan masyarakat. Oleh karena itu, pembelajaran sains yang berkualitas diharapkan dapat memecahkan berbagai masalah yang ditimbulkan oleh kemajuan IPTEK. Sayangnya, masih ditemukan peserta didik yang mengalami kesulitan dalam mempelajari materi kimia seperti termokimia.

Kesulitan yang dialami peserta didik dalam mempelajari konsep termokimia diantaranya (1) membedakan kalor dengan 
suhu, (2) prinsip kalorimeter dan pertukaran energi pada reaksi dalam kalorimeter, (3) mengidentifikasi reaksi eksoterm dan endoterm (Yalcinkaya et al., 2015). Pemahaman peserta didik terhadap konsep termodinamika juga masih rendah, diantaranya (1) hubungan antara energi, entalpi, dan ikatan dalam reaksi kimia, (2) perubahan panas, suhu, dan entalpi dalam perubahan fasa, (3) hubungan antara panas, suhu, masa dan kalor jenis (Saricayir et al., 2016).

Dari hasil wawancara dengan seorang guru bidang studi kimia di SMA Negeri 2 Percut Sei Tuan dijelaskan bahwa bahan ajar yang digunakan sejauh ini belum dapat merangsang lebih jauh keinginan siswa untuk mempelajari konsep termokimia. Akibatnya, pengkajian, pengelolaan, dan penyajian secara nyata dan langsung yang dilakukan siswa sangat minim untuk membantu dalam memahami konsep termokimia secara praktikal.

Kurikulum 2013 menekankan pelaksanaan pendekatan saintifik pada semua jenjang pendidikan (Permendikbud Nomor 59 Tahun 2014). Salah satu model pembelajaran yang sesuai dengan pendekatan saintifik dan diajurkan oleh kurikulum 2013 adalah pembelajaran berbasis proyek (Sari et al., 2017).

Model pembelajaran berbasis proyek mengacu pada filosofis konstruktivisme, yaitu pengetahuan merupakan hasil konstruksi kognitif melalui suatu aktivitas siswa yang meliputi keterampilan maupun sikap ilmiah siswa sehingga siswa dapat mengkonstruksi pengetahuannya sendiri dan bermaknamelalui pengalaman yang nyata. Kerja proyek memuat tugas-tugas yang kompleks berdasarkan kepada pertanyaan dan permasalahan (problem) yang sangat menantang dan menuntut siswa untuk merancang, memecahkan masalah, membuat keputusan, melakukan kegiatan investigasi, serta memberikan kesempatan kepada siswa untuk bekerja secara mandiri (Siwa et al., 2013)
Pembelajaran berbasis proyek telah lama digunakan dalam pendidikan yang lebih tinggi sebagai metode untuk mendidik siswa menggunakan tugas berbasis masalah yang realistis. Pembelajaran berbasis proyek melibatkan siswa dalam proses pembuatan keputusan dan membuat mereka akan merasa lebih terlibat dalam proyek pada keseluruhannya (Behizadeh, 2014).

Pembelajaran berbasis proyek memampukan siswa membangun pemahaman mereka sendiri dalam kolaborasi dengan teman sejawat. Pembelajaran berbasis proyek juga memberikan kesempatan kepada siswa menyajikan hasil pekerjaan mereka kepada audiens untuk dipresentasikan (Rose \& Prasetya, 2015). Disamping itu, pembelajaran berbasis proyek adalah salah satu model pembelajaran yang sesuai dengan pendekatan saintifik dan dianjurkan oleh kurikulum 2013 (Sari et al., 2017).

\section{KAJIAN LITERATUR}

\section{A. Pengertian Modul}

Modul adalah bahan ajar yang disusun secara sistematis dan menarik yang mencakup isi materi, metode, dan evaluasi yang dapat digunakan secara mandiri untuk mencapai kompetensi yang diharapkan (Sani, 2015). Modul adalah bahan ajar yg dirancang secara sistematis berdasarkan kurikulum tertentu dan dikemas dalam bentuk satuan pembelajaran terkecil dan memungkinkan dipelajari secara mandiri dalam satuan waktu tertentu agar siswa mampu menguasai kompetensi yang diajarkan (Khotim et al., 2015). Untuk menghasilkan modul yang mampu meningkatkan motivasi belajar, pengembangan modul harus memperhatikan karakteristik yang diperlukan sebagai modul, yaitu: a) Self instructional, b) Self Contained, c) Stand alone (berdiri sendiri).

\section{B. Tujuan dan Manfaat Modul}

Tujuan pengajaran modul adalah sebagai berikut:

1. Membuka kesempatan bagi peserta didik untuk belajar menurut kecepatan masingmasing.

2. Memberikan kesempatan bagi peserta 
didik untuk belajar menurut cara masingmasing karena mereka mungkin menggunakan teknik yang berbeda-beda dalam merencanakan masalah tertentu berdasarkan latar belakang pengetahuan dan kebiasaan masing-masing.

3. Memberikan pilihan dari sejumblah besar topic dalam suatu mata pelajaran jika dianggap susah bahwa peserta didik tidak mempunyai pola minat yang sama.

4. Memberikan kesempatan kepada pendidik untuk mengenal kelebihan dan kekurangannya dan memperbaiki kelemahannya.

Bagi guru, penyusunan modul bermanfaat karena:

1. Mengurangi ketergantungan terhadap ketersediaan buku teks.

2. Memperluas wawasan karena disusun dengan menggunakan berbagai refrensi

3. Menambah khazanah pengetahuan dalam menulis bahan ajar

4. Membangun komunikasi yang efektif antara dirinya dan siswa karena pembelajaran tidak harus berjalan secara tatap muka

5. Menambah angka kredit jika dikumpulkan menjadi buku dan diterbitkan.

\section{Unsur-Unsur Pembuatan Modul}

Ada tujuh unsur dalam pembuaatan modul adalah sebagai berikut :

1. Rumusan Tujuan Pengajaran yang Eksplisit dan Spesifik

Tujuan pengajaran dirumusakn dalam bentuk tingkah laku siswa. Tiap-tiap rumusan tujuan itu melukiskan tingkah laku mana yang diharapkan dari siswa setelah menyelesaikan tugasnya dalam mempelajari suatu modul. Rumusan tujuan pengajaran atau tujuan belajar ini tercantum pada dua bagian, yaitu : Pertama, lembar kegiatan siswa, untuk memberitahukan kepada mereka tingkah laku mana yang diharapkan dari mereka setelah berhasil menyelesaikan modul. Kedua, petunjuk guru, untuk memberitahukan kepada guru tingkah laku atau pengetahuan siswa yang mana yang seharusnya telah dimiliki oleh siswa setelah mereka merampungkan yang bersangkutan.

2. Pentunjuk Penggunaan Modul
Petunjuk untuk guru ini berisi keterangan tentang bagaimana pengajaran itu dapat diselenggarakan secara efisien. Petunjuk guru juga berisi penjelasan tentang jenis-jenis kegiatan yang mesti dilakukan oleh siswa di kelas, waktu yang disediakan untuk menyelesaikan modul yang bersangkutan, alat-alat pelajaran dan sumber yang harus digunakan, prosedur evaluasi, dan jenis alat evaluasi yang digunakan.

3. Lembar Kegiatan Siswa

Lembaran ini memuat materi pelajaran yang harus dikuasai oleh siswa. Materi dalam lembaran kegiatan siswa ini disusun secara khusus sedemikian rupa sehingga dengan mempelajari materi tesebut tujuan yang telah dirumuskan dalam modul tersebut dapat tercapai. Dalam lembaran kegiatan ini dicantumkan pula kegiatan (pengamatan, percobataan dan sebagainya) yang harus dilakukan oleh siswa. Dicantumkan pula buku-buku yang harus dipelajari siswa sebagai pelengkap materi yang terdapat dalam modul

\section{Lembaran Kerja Siswa}

Materi pelajaran dalam lembar kegiatan tersebut disusun sedemikian rupa sehingga siswa secara aktif dalam proses belajar. Dalam lembaran kegiatan ini, dicantumkan pernyataan dan masalahmasalah yang harus dijawab dan dipecahkan oleh siswa. Sementara itu, lembar kerja yang menyertai kegiatan siswa digunakan untuk menjawab pertanyaan dan memecahkan masalah tersebut. Pada lembar kegiatan, siswa dilarang membuat coretan apapun, karena buku modul itu akan digunakan oleh para siswa lain di waktu-waktu yang akan mendatang. Semua kegiatan siswa dilakukan pada kertas lembaran kerja.

5. Lembaran Evaluasi

Perlu diketahui bahwa lembaran evaluasi berupa test dan rating scale. Evaluasi guru terhadap tercapai atau tidakya tujuan yang dirumusakan pada modul oleh siswa ditentukan oleh hasil tes akhir yang terdapat pada lembar evaluasi tersebut dan jawabanjawaban siswa pada lembar kerja. Para siswa malas yang hanya menyalin kunci jawaban ke dalam lebaran kerjanya akan segera sadar, 
bahwa dengan cara belajar ia tidak akan siap menghadapi tes akhir yang diberikan oleh guru. Lembaran evaluasi dan kunci ini senantiasa disimpan oleh guru sendiri.

6. Kunci jawaban Lembaran Evaluasi

Dalam hal ini tes dan rating scale yang tercantum pada lembaran evaluasi tersebut disusun oleh penulis modul dalam item tes. Adapun item tes tersebut disusun dan dijabarkan dari rumusan tujuan pada modul. Oleh sebab itu, dari hasil jawaban teks soal tersebut dapat diketahui tercapai tidaknya tujuan yang dirumuskan pada modul yang bersangkutan. Dan kunci jawaban tes dan rating scale juga disusun oleh penulis modul (Sani, 2015).

\section{STANDAR KELAYAKAN BAHAN AJAR BERSTANDAR BSNP}

Badan standar nasional pendidikan (BSNP) merupakan lembaga independen yang memiliki kewenangan dalam menetapkan kelayakan buku teks pelajaran untuk digunakan disekolah. BSNP dibentuk berdasarkan peraturan Pemerintah No. 19 tahun 2005 dengan tugas : a) mengembangkan standar nasional pendidikan, b) menyelenggarakan ujian nasional, c) memberikan rekomendasi kepada pemerintah dan pemerintah daerah dalam penjaminan dan pengendalian mutu pendidikan, d) merumuskan kriteria kelulusandari satuan pendidikan pada jenjang pendidikan dasar dan menengah, dan e) menilai kelayakan isi, kelayakan penyajian, kelayakan bahasa, dan kelayakan kegrafikan buku teks pelajaran.

\section{E. Karakter Pembelajaran Berbasis Proyek}

Elemen-elemen utama dalam pembelajaran berbasis proyek, yaitu: pengantar, defenisi tugas pembelajaran, prosedur investigasi, sumber yang disarankan, mekanisme, kolaborasi, serta refleksi, dan transfer kegiatan. Karakteristik pembelajaran berbasis proyek meliputi aspek isi, kegiatan, kondisi, dan hasil. Dalam pembelajaran berbasis proyek, aspek isi pembelajaran memiliki karakteristik : a) masalah disajikan dalam bentuk keutuhan yang kompleks; b) siswa menemukan hubungan antar ide secara interdisipliner; c) siswa berjuang mengatasi ambiguitas; dan d) menjawab pertanyaan yang nyata dan menarik perhatian siswa. Aspek kegiatan memiliki karakteristik : a) siswa melakukan investigasi selama periode tertentu; b) siswa dihadapkan pada suatu kesulitan, pencarian sumber dan pemecahan masalah; c) siswa membuat hubungan antar ide dan memperoleh keterampilan baru; d) siswa menggunakan perlengkapan alat sesungguhnya; dan e) siswa menerima feedback tentang gagasannya dari orang lain. Aspek kondisi mencakup karakteristik : a) siswa berperan sebagai masyarakat pencari dan melakukan latihan kerjanya dalam konteks sosial; b) siswa mempraktikan perilaku manajemen waktu dalam melaksanakan tugas secara individu maupun kelompok; c) siswa mengarahkan kerjanya sendiri dan melakukan kontrol belajarnya; dan d) siswa melakukan simulasi kerja professional. Yang terakhir adalah aspek hasil. Karakteristik aspek hasil meliputi: a) siswa menghasilkan produk intelektual yang kompleks sebagai hasil belajarnya; b) siswa terlibat dalam melakukan penilaian diri; c) siswa bertanggung jawab terhadap pilihannya dalam mendemonstrasikankompetensi mereka; dan d) siswa memperagakan kompetensi nyata mereka.

Back Institute for Education memberikan karakteristik pembelajaran berbasis proyek yaitu:

1. Siswa membuat keputusan dan membuat kerangka kerja;

2. Terdapat masalah yang pemecahannya tidak ditentukan sebelumnya;

3. Siswa merancang proses untuk mencapai hasil;

4. Siswa bertanggung jawab mendapatkan dan mengelolainformasi yang dikumpulkan;

5. Siswa melakukan evaluasi secara kontiniu;

6. Siswa secara teratur melihat kembali apa yang mereka kerjakan;

7. Hasil akhir berupa produk dan dievaluasi kualitasnya;

8. Atmosfir kelas memberi toleransi kesalahan dan perubahan. 


\section{F. Langkah-Langkah Pembelajaran Berbasis Proyek}

Menurut The George Lucas

Educational Foundation, langkah-langkah Project Based Learning adalah sebagai berikut :

1. Mulai dengan pertanyaan esensial

Pembelajaran dimulai dengan pertanyaan esensial, yaitu pertanyaan yang mendorong siswa untuk melakukan suatu aktivitas.

2. Membuat desain rencana proyek

Siswa dengan pendampingan dari guru membuat desain rencana proyek yang akan dilakukan. Rencana proyek ditentukan oleh siswa sendiri mengacu kepada pertanyaan esensial yang telah dikemukakan sebelumnya.

3. Membuat jadwal

Guru dan siswa secara kolaboratif menyusun jadwal pelaksanaan kegiatan pembelajaran. Aktivitas pada tahap ini antara lain: (1) membuat timeline untuk menyelesaikan proyek, (2) membuat deadline penyelesaian proyek, (3) mengarahkan siswa agar merencanakan cara yang baru, (4) mengarahkan siswa ketika mereka membuat cara yang tidak berhubungan dengan proyek, dan (5) meminta siswa untuk memberi alas an tentang cara yang dipilih.

4. Memantau siswa dan kemajuan proyek

Guru bertanggung jawab memantau kegiatan siswa selama menyelesaikan proyek untuk mengetahui kemajuan pelaksanaan proyek dan mengantisipasi hambatan yang dipilih siswa.

5. Menilai hasil

Penilaian dilakukan untuk mengukur ketercapaian standar, mengevaluasi kemajuan masing-masing siswa, memberi umpan balik, tentang tingkat pemahaman yang sudah dicapai, dan menjadi bahan pertimbangan dalam menyusun strategi pembelajaran berikutnya.

6. Refleksi

Pada akhir pembelajaran, guru dan siswa melakukan refleksi terhadap aktivitas dan hasil proyek yang sudah dijalankan. Proses refleksi dilakukan secara individu maupun kelompok.

\section{G. Kelebihan dan Kekurangan Pembelajaran Berbasis Proyek}

Ada beberapa kelebihan dalam menerapkan model pembelajaran berbasis proyek bagi siswa, guru, dan perkembangan sekolah menurut yaitu :

1. Memperoleh pengetahuan dan keterampilan baru dalam pembelajaran

2. Meningkatkan kemampuan peserta didik dalam pemecahan masalah

3. Membuat peserta didik lebih aktif dalam memecahkan masalah yang kompleks dengan hasil produk nyata berupa barang atau jasa

4. Peserta didik membuat keputusan dan membuat kerangka kerja

5. Peserta didik merancang proses untuk mencapai hasil

6. Peserta didik bertanggung jawab untuk mendapatkan dan mengelola informasi yang dikumpulkan

7. Peserta didik melakukan evaluasi secara kontinu

8. Peserta didik secara teratur melihat kembali apa yang mereka kerjakan.

Beberapa kekurangan dari model pembelajaran berbasis proyek diantaranya sebagai berikut :

1. Kebanyakan permasalahan dunia nyata yang tidak terpisahkan dengan masalah kedisplinan

2. Memerlukan banyak waktu untuk menyelesaikan masalah

3. Membutuhkan biaya yang cukup banyak

4. Banyak instruktur yang merasa nyaman dengan kelas tradisional

Banyaknya peralatan yang harus disediakan

\section{METODE}

Penelitian ini dilaksanakan di SMA Negeri 2 Percut Sei Tuan yang beralamat di Jl. Pendidikan Pasar XII Desa Bandar Klippa pada semester genap Tahun Ajaran 2020/2021, yaitu pada bulan Januari sampai April 2021.

Populasi pada penelitian ini adalah (1) Semua dosen jurusan Kimia Universitas Negeri Medan, (2) semua guru mata pelajaran Kimia SMA Negeri 2 Percut Sei Tuan, (3) Semua siswa jurusan IPA Kelas XI SMA 
Negeri 2 Percut Sei Tuan Tahun Ajaran 2020/2021

Sampel yang ditetapkan pada penelitian ini adalah sebagai berikut :

1. Dosen Kimia Universitas Negeri Medan yang dipilih secara purposive sampling sebanyak 3 orang sebagai validator ahli terhadap modul pembelajaran kimia berbasis proyek yang akan dikembangkan

2. Guru Kimia SMA Negeri 2 Percut Sei Tuan secara keseluruhan sebanyak 3 orang sebagai validator ahli terhadap modul pembelajaran kimia berbasis proyek yang akan dikembangkan

3. Siswa IPA Kelas XI SMA Negeri 2 Percut Sei Tuan sebanyak 1 kelas dengan jumlah siswa sebanyak 20 orang.

Teknik analisis data kualitatif diperoleh dari hasil penelitian pada angket yang berisi standar penilaian bahan ajar BSNP. Modul yang telah dikembangkan akan distandarisasi atau dianalisis menggunakan analisis deskriptif persentase.

Instrumen dalam penelitian ini menggunakan angket penilaian BSNP. Untuk memperoleh data angket penilaian BSNP pada dosen dan guru, dilakukan dengan membagikan angket penilaian BSNP beserta bahan ajar yang telah dikembangkan yang akan dinilai kepada masing-masing dosen dan guru yang bersangkutan. Pada penelitian ini, jenis angket yang digunakan yaitu angket penilaian BSNP berupa validasi kelayakan isi, kebahasaan, penyajian, dan kegrafikan. Angket tersebut akan diisi oleh validator ahli yaitu Dosen Kimia UNIMED dan Guru Kimia SMA SMA Negeri 2 Percut Sei Tuan berdasarkan modul pembelajaran kimia berbasis proyek pada pokok bahasan termokimia sesuai kurikulum 2013.

Desain penelitian yang digunakan pada penelitian ini adalah Penelitian dan Pengembangan atau lebih dikenal dengan Research and Development (R\&D). Model pengembangan yang digunakan dalam pengambangan bahan ajar ini adalah ADDIE (Analysis, Design, Development, Implementation, Evaluation) ADDIE merupakan salah satu model desain pembelajaran sistematik yang terdiri atas 5 tahapan, yakni: tahap pertama itu yaitu tahap analisis, tahap kedua yaitu tahap desain, tahap ketiga yaitu tahap pengembangan, yang keempat itu tahap implementasi, tahap kelima yaitu tahap evaluasi.

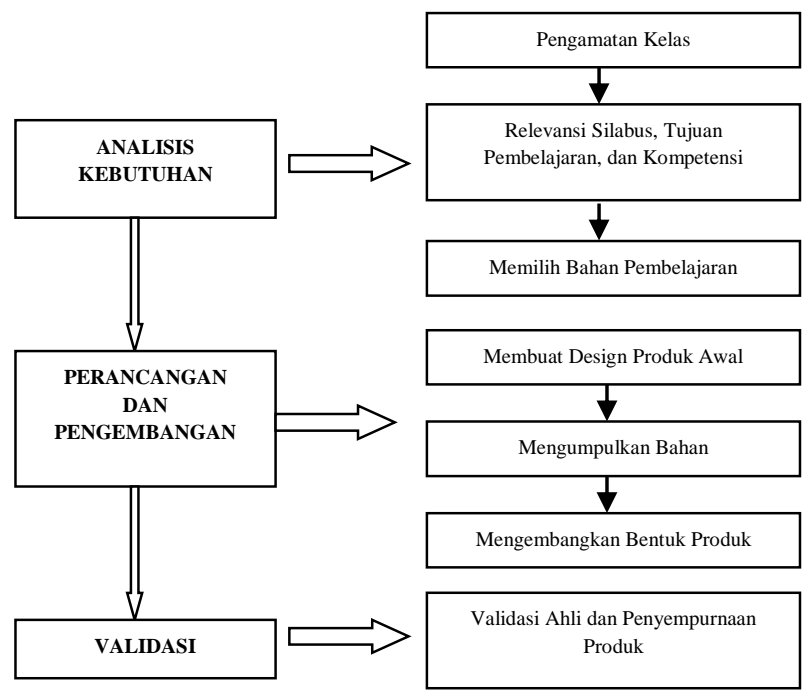

Gambar 1. Prosedur Penelitian

Data yang diperoleh dari penelitian adalah berupa data kualitatif yang diperoleh dari penilaian dan revisi sampai dihasilkan produk berupa modul pembelajaran kimia berbasis proyek pada pokok bahasan termokimia. Data kualitatif dianalisis dengan menggunakan analisis deskriptif. Analisis deskriptif persentasi digunakan untuk mendeskripsikan persentase masing-masing variabel. Data yang diperoleh berdasarkan angket validasi bahan ajar dan angket lembar penilaian modul oleh peserta didik akan diolah dengan cara statistik deskriptif.

Skala penilaian yang digunakan pada angket kelayakan Badan Standar Nasional Pendidikan (BSNP) yang dimodifikasi adalah 1 sampai 4, dimana 1 sebagai skor terendah dan 4 sebagai skor tertinggi dengan urutan penilaian $1=$ sangat tidak setuju, $2=$ tidak setuju, 3 = setuju, $4=$ sangat setuju. Teknik analisis data yang digunakan untuk menganalisis data hasil validasi dari dosen adalah teknik rata - rata. Rumus yang digunakan untuk menghitung data hasil 
pengisian angket adalah dengan perhitungan rata - rata yaitu:

$$
\bar{x}=\frac{\sum X}{n}
$$

Tabel 1. Kriteria Validitas

\begin{tabular}{ll}
\hline Rata-rata & Kriteria Validitas \\
\hline $3,26-4,00$ & sangat layak \\
$2,51-3,25$ & Layak \\
$1,76-2,50$ & Kurang layak \\
$1,00-1,75$ & Tidak layak \\
\hline
\end{tabular}

Tabel 1. Kriteria Respon Peserta Didik

\begin{tabular}{ll} 
Interval Presentase & \multicolumn{1}{c}{ Kriteria } \\
\hline $85 \%$ s/d $100 \%$ & Sangat Tinggi \\
$70 \%$ s/d $83,75 \%$ & Tinggi \\
$55 \%$ s/d $68,75 \%$ & Sedang \\
$40 \%$ s/d $53,75 \%$ & Rendah \\
$25 \%$ s/d $38,75 \%$ & Sangat Rendah \\
\hline
\end{tabular}

\section{HASIL DAN PEMBAHASAN}

\section{Analisis Bahan Ajar SMA}

Berpedoman pada sintaks project besed learning dilakukan analisis terhadap bahan ajar di SMA Negeri 2 Percut Sei Tuan untuk mengetahui kelayakan sebagai bahan ajar berbasis project based learning. Bahan ajar A, B, dan C diatas selanjutnya dianalisis, meliputi tiga aspek yaitu: (1) ditinjau dari komponen bahan ajar, (2) ditinjau dari materi bahan ajar, dan (3) ditinjau dari sintaks Project Based Learning. Hasil penilaian aspek ketiga dapat dilihat pada tabel 3 .

Tabel 3. Skor analisis bahan ajar

\begin{tabular}{ccl}
\hline $\begin{array}{c}\text { Kode Bahan } \\
\text { Ajar }\end{array}$ & $\begin{array}{c}\text { Rata-Rata } \\
\text { Skor }\end{array}$ & $\begin{array}{l}\text { Kriteria } \\
\text { Kelayakan }\end{array}$ \\
\hline $\mathbf{A}$ & 1,44 & Tidak layak \\
$\mathbf{B}$ & 2,66 & Layak \\
$\mathbf{C}$ & 1,44 & Tidak layak \\
\hline
\end{tabular}

Skor analisis bahan ajar

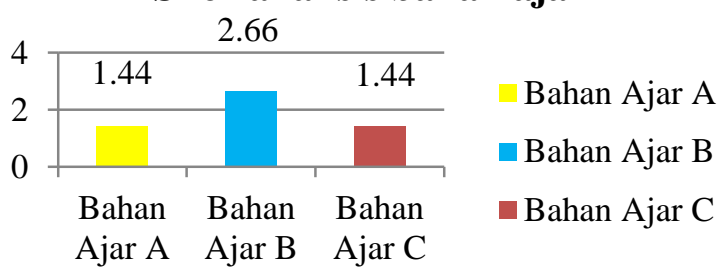

Gambar 2. Skor analisis bahan ajar

\section{Validasi Sintaks Model Pjbl Dalam Modul}

Validasi sintaks modul pembelajaran termokimia berbasis projek menggunakan instrumen sintaks Project Based Learning. Hasil validasi sintaks modul pembelajaran termokimia berbasis Project Based Learning dapat dilihat pada tabel 4.

Tabel 4. Hasil Validasi Sintaks PjBL

\begin{tabular}{|c|c|c|c|c|}
\hline \multirow[t]{2}{*}{ Validator } & \multicolumn{4}{|c|}{ Komponen Penilaian } \\
\hline & Isi & Kegiatan & Kondisi & Hasil \\
\hline D1 & 3,50 & 3,60 & 3,00 & 3,00 \\
\hline G1 & 2,00 & 3,00 & 3,00 & 3,00 \\
\hline $\mathrm{G} 2$ & 4,00 & 3,60 & 4,00 & 4,00 \\
\hline G3 & 3,00 & 3,00 & 4,00 & 4,00 \\
\hline Rata-rata & 3,12 & 3,30 & 3,50 & 3,50 \\
\hline Kriteria & Layak & $\begin{array}{c}\text { Sangat } \\
\text { layak }\end{array}$ & $\begin{array}{c}\text { Sangat } \\
\text { layak }\end{array}$ & $\begin{array}{c}\text { Sangat } \\
\text { layak }\end{array}$ \\
\hline
\end{tabular}

\section{Hasil Validasi Sintaks Model PjBL}

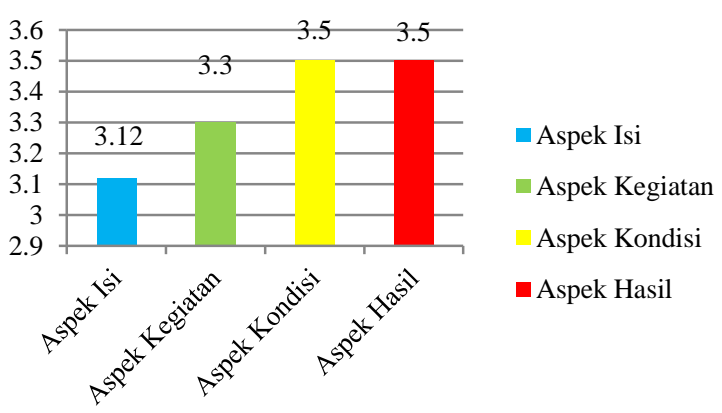

Gambar 3. Hasil Validasi Sintaks Model PjBL

\section{Pengembangan Modul}

Rancangan yang telah ditetapkan selanjutnya dikembangkan untuk menghasilkan produk berupa modul sebagai bahan ajar yang dapat dibaca, dipahami, dan dipraktikan secara langsung oleh peserta didik.

Komponen yang dikembangkan antara lain: 1) cover modul, 2) petunjuk penggunaan modul, 3) standar kompetensi, 4) peta konsep, 5) komponen tambahan modul, 6) Project kimia, 8) contoh soal dan latihan, 9) rangkuman materi, 10) glosarium, 11) uji kompetensi, 12) kunci jawaban, dan 13) daftar pustaka. 


\section{Validasi Materi Modul}

Hasil penilaian materi dari modul berbasis projek menggunakan instrumen BSNP yang dinilai oleh validator ahli materi yang terdiri dari 1 dosen kimia UNIMED dan 3 guru kimia dengan rata-rata hasil validasi seperti table 4.

Tabel 4. Hasil validasi materi

\begin{tabular}{ccc}
\hline \multirow{2}{*}{ Validator } & \multicolumn{2}{c}{ Penilaian } \\
& Isi & Penyajian \\
\hline D1 & 3,00 & 3,50 \\
G1 & 2,00 & 3,00 \\
G2 & 4,00 & 3,00 \\
G3 & 3,00 & 3,00 \\
Rata-rata & $\mathbf{3 , 0 0}$ & $\mathbf{3 , 1 2}$ \\
Kriteria & Layak & Layak \\
\hline
\end{tabular}

Hasil Validasi Materi

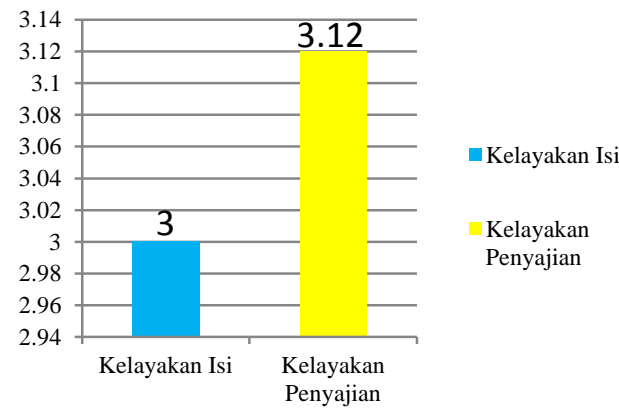

Gambar 4. Hasil validasi materi

\section{Validasi Modul}

Hasil penilaian dari modul berbasis projek menggunakan instrumen BSNP yang dinilai oleh validator ahli media yang terdiri dari 3 dosen kimia UNIMED dengan rata-rata hasil validasi seperti tabel 5

Tabel 5. Hasil Validasi Modul

\begin{tabular}{ccc}
\hline Validator & \multicolumn{2}{c}{ Penilaian } \\
& Grafik & Bahasa \\
\hline D1 & 3,52 & 3,50 \\
D2 & 3,63 & 4,00 \\
D3 & 2,63 & 3,00 \\
Rata-rata & 3,26 & 3,50 \\
Kriteria & $\begin{array}{c}\text { Sangat } \\
\text { layak }\end{array}$ & $\begin{array}{c}\text { Sangat } \\
\text { layak }\end{array}$ \\
\hline
\end{tabular}

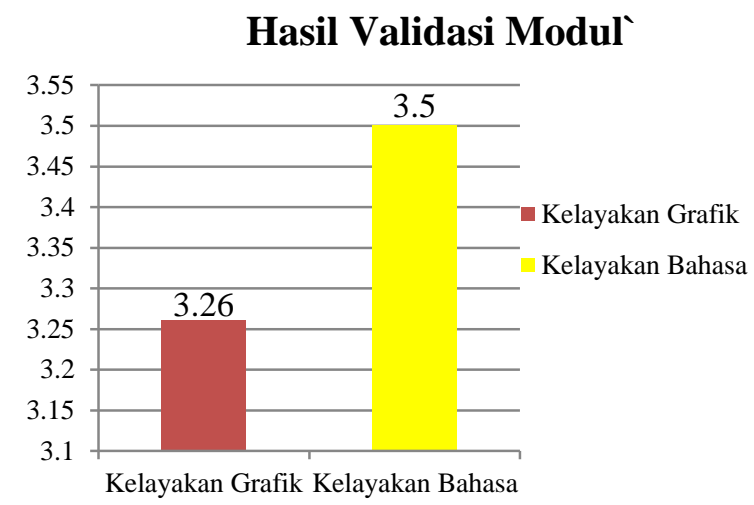

Gambar 5. Hasil validasi modul

\section{Respon Siswa Terhadap Modul}

Setelah modul yang dikembangkan divalidasi oleh dosen ahli dan guru mata pelajaran Kimia yang di anggap ahli dengan memberikan penilaian berupa skor, komentar dan saran. Selanjutnya buku ajar ini diujikan ke siswa untuk menilai respon mereka terhadap modul yang dikembangkan. Hasil penilaian dirangkum dalam tabel 4.6.

Tabel 4. 1 Persentase Respon Siswa Terhadap Modul

\begin{tabular}{ccc}
\hline $\begin{array}{c}\text { Komponen } \\
\text { Penilaian }\end{array}$ & Persentase & Kriteria \\
\hline Tampilan & $93,75 \%$ & Sangat tinggi \\
Materi & $95 \%$ & Sangat tinggi \\
Manfaat & $95,9 \%$ & Sangat tinggi \\
\hline
\end{tabular}

\section{Persentase Respon Siswa Terhadap Modul}

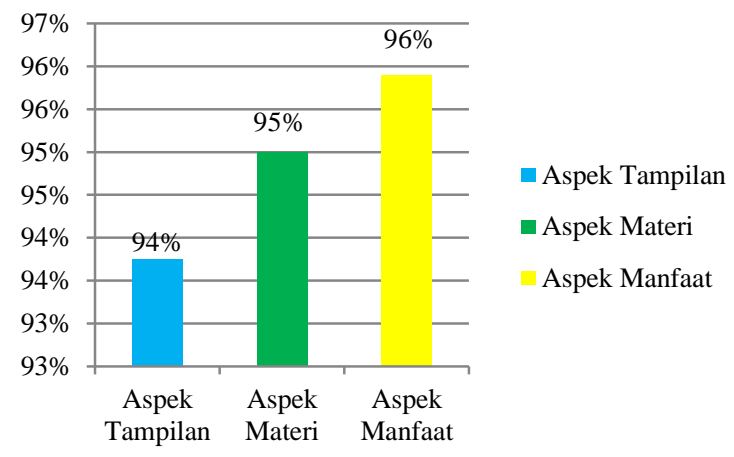

Gambar 6. Persentase Respon Siswa Terhadap Modul 


\section{DISKUSI}

Tujuan penelitian ini adalah untuk mengetahui apakah modul kimia berbasis project based learning (PjBL) sesuai dengan sintaks project based learning, kriteria kelayakan isi, kelayakan bahasa, kelayakan penyajian dan kelayakan kegrafikan. Model pengembangan yang digunakan dalam pengambangan bahan ajar ini adalah ADDIE (Analysis, Design, Development, Implementation, Evaluation) yang dibatasi hingga tahap implementasi.

Langkah awal dalam penelitian ini adalah Berpedoman pada sintaks project besed learning dilakukan analisis terhadap bahan ajar di SMA Negeri 2 Percut Sei Tuan untuk mengetahui kelayakan sebagai bahan ajar berbasis project based learning. Analisis yang dilakukan ditinjau dari kelengkapan komponen bahan ajar, komponen materi bahan ajar, dan sintaks project based learning.

Hasil analisis penyajian menunjukkan buku $\mathrm{A}$ dan $\mathrm{C}$ kurang memenuhi kriteria sebagai buku yang dikembangkan berdasarkan Project Based Learning dengan nilai 1,44. Sementara itu buku B masih tergolong layak sebagai buku yang dikembangkan berdasarkan Project Based Learning dengan nilai sebesar 2,66.

Langkah yang dilakukan setelah analisis adalah rancangan dan pengembangan modul berbasis proyek. Rancangan dan pengembangan isi modul menggunakan referensi dari ketiga buku kimia yang memiliki pokok bahasan termokimia dengan pengarang yang berbeda. Bukan hanya buku yang dianalisis referensi pembuatan modul juga bersumber dari berbagai literatur misalnya internet.

Modul termokimia berbasis Project based learning yang telah selesai dikembangkan kemudian divalidasi dengan menggunakan sintaks PjBL dengan memperhatikan aspek isi, aspek kegiatan, aspek kondisi, dan aspek hasil. Berdasarkan hasil validasi (sintaks) model PjBL dalam modul memiliki nilai rata-rata skor aspek isi sebesar 3,12 dan termasuk dalam katagori cukup valid dan tidak perlu direvisi. Dari segi aspek kegiatan memiliki rata-rata skor 3,30, aspek kondisi dengan rata-rata 3,50, dan aspek hasil dengan rata-rata 3,50 dan termasuk kedalam kategori valid dan tidak perlu direvisi. Skor rata-rata keseluruhan sebesar 3,35.

Modul termokimia berbasis project based learning setelah selesai dikembangkan dan disusun sesuai unsur-unsur modul dengan memperhatikan isi dan penyajiannya, selanjutnya bahan ajar modul tesebut distandarisasi kepada validator media yaitu 3 dosen kimia UNIMED dan validator materi 1 dosen kimia UNIMED dan 3 guru SMA N 2 Percut Sei Tuan sehingga diperoleh hasil penilaian untuk kelayakan isi sebesar 2,98 dengan kriteria layak ; dan kelayakan penyajian sebesar 3,36 dengan kriteria sangat layak ; kelayakan grafik sebesar 3,33 dengan kriteria sangat layak ; kelayakan bahasa sebesar 3,36 dengan kriteria sangat layak sehingga rata-rata dari keempat aspek kelayakan tersebut sebesar 3,26 dengan kriteria sangat layak.

Hal ini dapat disimpulkan bahwa modul termokimia berbasis Project Based Learning yang telah dikembangkan oleh peneliti sudah layak dan tidak perlu direvisi. sesuai dengan kriteria validitas rata-rata BSNP, angka tersebut berada pada kisaran 3,26 - 4,00 yang berarti bahwa modul pembelajaran kimia berbasis Project Based Learning (PjBL) pada pokok bahasan termokimia telah valid dan tidak perlu direvisi. Jadi, modul pembelajaran termokimia ini dapat digunakan dalam proses pembelajaran.

Setelah modul berbasis Project Based Learning ini valid, kemudian penilaian dilanjutkan kepada respon siswa dengan tujuan untuk melihat persentasi tingkat kepuasan siswa terhadap modul yang sudah dikembangkan bersadarkan aspek tampilan, aspek materi dan aspek manfaat. Diperoleh hasil dari 20 orang responen yaitu aspek tampilan sebesar 93,75\% aspek materi sebesar 95\% dan aspek manfaat sebesar 95,9\%. Ratarata persentasi tingkat kepuasan siswa terhadap modul yang sudah dikembangkan sebesar 94,88\% dengan kriteria sangat tinggi. 
Hasil penelitian ini sejalan dengan penilitan pengembangan yang dilakukan oleh (Purba \& Siregar, 2020)dijelaskan dalam hasil penelitian tersebut bahwa modul berbasis Project Based Learning dapat meningkatkan hasil belajar siswa. Jika dijabarkan, bahwa siswa memiliki respon yang baik terhadap modul berbasis Project Based Learning sehingga hasil belajar siswa dapat meningkatkan.

Dalam pengembangan modul berbasis Project Based Learning ditemukan beberapa kelemahan dan kelebihan. Hal ini tidak terlepas dari betapa kompleksnya suatu modul yang harus dikembangkan. Adapun kelebihan pengembangan modul berbasis Project Based Learning antara lain (1) modul mudah dikembangkan (2) banyak referensi / literatur pendukung pembuatan modul, pengembangan modul tidak memakan waktu yang banyak dikarenakan telah terstruktur oleh draf rancangan modul. Adapun kekurangan pengembangan modul berbasis Project Based Learning adalah (1) pemilihan project yang tepat untuk digunakan dalam modul agar mudah untuk dipahami pembaca (2) pencetakan dikemudian hari membutuhkan biaya yang tidak sedikit.

Maka berdasarkan hasil penelitian yang telah dilakukan dapat disimpulkan bahwa modul pembelajaran termokimia berbasis proyek valid dengan kriteria nilai responsi siswa sangat tinggi.

gan kriteria kelayakan isi, kelayakan bahasa, kelayakan penyajian dan kelayakan kegrafikan. Model pengembangan yang digunakan dalam pengambangan bahan ajar ini adalah ADDIE (Analysis, Design, Development, Implementation, Evaluation) yang dibatasi hingga tahap implementasi.

Langkah awal dalam penelitian ini adalah menganalisis silabus dan bahan ajar sebagai dasar dalam pembuatan modul. Menganalisis silabus bertujuan untuk mengetahui materi yang harus dimuat dalam modul dan mengetahui kompetensi yang harus dicapai sebagai tujuan pembelajaran dengan modul berbasis proyek ini. Sementara analisis buku kimia kelas XI SMA oleh peneliti dilakukan dengan melakukan penelitian buku pegangan siswa sebanyak 3 buku dianalisis sesuai dengan materi pokok termokimia.

Analisis yang dilakukan ditinjau dari kelengkapan isi buku dan sub pokok bahasan dalam materi termokimia. Hasil analisis dapat disimpulkan bahwa komponen yang terdapat pada buku pegangan siswa perlu dimuat dalam modul. Adapun komponen yang dimuat dalam modul berdasarkan referensi ketiga buku adalah pengantar, glosarium, daftar pustaka, tabel periodik unsur, kunci jawaban, rangkuman, dan soal evaluasi. Kelebihan yang ditemukaan dalam buku ajar diintegrasikan untuk pengembangan modul berbasis proyek.

Langkah yang dilakukan setelah analisis adalah rancangan dan pengembangan modul berbasis proyek. Rancangan dan pengembangan isi modul menggunakan referensi dari ketiga buku kimia yang memiliki pokok bahasan termokimia dengan pengarang yang berbeda. Bukan hanya buku yang dianalisis referensi pembuatan modul juga bersumber dari berbagai literatur misalnya internet.

Bahan ajar modul berbasis proyek pada materi termokimia setelah selesai dikembangkan dengan memperhatikan isi dan penyajiannya, selanjutnya bahan ajar modul tesebut distandarisasi kepada validator media yaitu 3 dosen kimia UNIMED dan validator materi 1 dosen kimia UNIMED dan 3 guru SMA N 2 Percut Sei Tuan sehingga diperoleh hasil penilaian untuk kelayakan grafik sebesar 3,33 dengan kriteria sangat layak ; kelayakan bahasa sebesar 3,36 dengan kriteria sangat layak ; kelayakan isi sebesar 2,98 dengan kriteria layak ; dan kelayakan penyajian sebesar 3,36 dengan kriteria sangat layak sehingga rata-rata dari keempat aspek kelayakan tersebut sebesar 3,26 dengan kriteria sangat layak.

Hal ini dapat disimpulkan bahwa bahan ajar modul berbasis masalah pada materi termokimia yang telah dikembangkan oleh peneliti sudah layak dan tidak perlu direvisi. sesuai dengan kriteria validitas ratarata BSNP, angka tersebut berada pada kisaran 3,26 - 4,00 yang berarti bahwa modul 
pembelajaran kimia berbasis Project Based Learning (PjBL) pada pokok bahasan termokimia telah valid dan tidak perlu direvisi. Jadi, modul pembelajaran kimia ini dapat digunakan dalam proses pembelajaran.

Setelah modul berbasis Project Based Learning ini valid, kemudian penilaian dilanjutkan kepada respon siswa dengan tujuan untuk melihat persentasi tingkat kepuasan siswa terhadap modul yang sudah dikembangkan bersadarkan aspek tampilan, aspek materi dan aspek manfaat. Diperoleh hasil dari 20 orang responen yaitu aspek tampilan sebesar $93,75 \%$ aspek materi sebesar 95\% dan aspek manfaat sebesar 95,9\%. Ratarata persentasi tingkat kepuasan siswa terhadap modul yang sudah dikembangkan sebesar 94,88\% dengan kriteria sangat tinggi.

\section{KESIMPULAN}

Berdasarkan hasil analisis yang telah dilakukan dalam penelitian ini , maka didapat kesimpulan sebagai berikut :

Berdasarkan hasil validasi bahan ajar kimia yang digunakan di Sekolah Menengah Atas (SMA) pada materi termokimia belum berbasis Project Based Learning hal ini dapat dilihat dari hasil analisis diperoleh rata-rata 1,85 dengan kriteria kurang valid.

Modul pembelajaran kimia yang dikembangkan pada materi termokimia sudah sesuai dengan kriteria yang telah ditetapkan oleh Badan Standar Nasional Pendidikan (BSNP). Hal ini dapat dilihat rata-rata dari hasil penilaian berdasarkan instrumen BSNP oleh dosen Kimia FMIPA UNIMED sebesar 3,38 dan guru Kimia SMA sebesar 3,06 yang menyatakan bahwa modul layak dan tidak perlu direvisi.

Modul pembelajaran kimia yang dikembangkan pada materi termokimia telah memenuhi kajian project based learning (PjBL). Hal ini ditunjukkan pada perolehan hasil integrasi model Project Based Learning (PjBL) pada modul yang diberikan oleh validator diperoleh ratarata 3,35 dengan kriteria valid dan tidak perlu direvisi.

Modul berbasis Project Based Learning (PjBL) pada pokok bahasan termokimia untuk kelas XI SMA/MA dinilai aspek tampilan, aspek materi dan aspek manfaat oleh siswa kelas XI SMA Negeri 2 Percut Sei Tuan dan diperoleh nilai 94,88\%.

\section{DAFTAR PUSTAKA}

Behizadeh, N. (2014). Enacting problemposing education through project-based learning. English Journal, 104(2), 99104.

Khotim, H. N., Nurhayati, S., \& Hadisaputro, S. (2015). Pengembangan Modul Kimia Berbasis Masalah Pada Materi Asam Basa. Chemistry in Education, 4(2), 6369.

Purba, J., \& Siregar, N. (2020). Pengembangan Bahan Ajar Berbasis Proyek Di SMA Negeri 2 Lintongnihuta pada materi Asam dan Basa. Jurnal Inovasi Pembelajaran Kimia, 2(2), 110115.

https://doi.org/10.24114/jipk.v2i2.19619

Rose, R. A., \& Prasetya, A. T. (2015). Keefektifan Strategi Project Based Learning Berbantuan Modul Pada Hasil Belajar Kimia Siswa. Jurnal Inovasi Pendidikan Kimia, 8(2), 1360-1369.

Sani, M. (2015). Pengembangan Modul Pembelajaran Berbasis Proyek Pada Mata Kuliah Pemeliharaan dan Perbaikan Mesin Listrik Di Jurusan Teknik Elektro Universitas Negeri Surabaya. Jurnal Pendidikan Teknik Elektro, 4(1), 259-267.

Sari, D. N. A., Rusilowati, A., \& Nuswowati, M. (2017). Pengaruh Pembelajaran Berbasis Proyek terhadap Kemampuan Literasi Sains Siswa. Pancasakti Science Education Journal, 2(2), 114-124.

Saricayir, H., Ay, S., Comek, A., Cansiz, G., \& Uce, M. (2016). Determining Students' Conceptual Understanding Level of Thermodynamics. Journal of Education and Training Studies, 4(6), 69-79.

https://doi.org/10.11114/jets.v4i6.1421

Siwa, I. B., Muderawan, I. W., \& Tika, I. N. (2013). Pengaruh Pembelajaran Berbasis Proyek dalam Pemebalajaran Kimia 
terhadap Keterampilan Proses Sains ditinjau dari Gaya Kognitif Siswa. EJournal Program Pascasarjana Universitas Pendidikan Ganesha, 3(3), $1-13$.

Yalcinkaya, F., Yalcinkaya, B., \& Jirsak, O. (2015). Influence of salts on electrospinning of aqueous and nonaqueous polymer solutions. Journal of Nanomaterials, 1-13. https://doi.org/10.1155/2015/134251 